\title{
Lessons from the conservation sector's response to a crisis environment in Zimbabwe
}

\author{
Mxolisi Sib ANDA
}

\begin{abstract}
Here I examine how conservation organizations responded to a crisis environment in Zimbabwe. Since c. 2000 Zimbabwe has gone through a political, social and economic crisis that has led to reduced support for, and in some cases disengagement by, international and regional conservation organizations. I explore five response types on a continuum of disengagement and propose lessons for wider conservation practice. The lessons include the need to recognize that political discourse often excludes biodiversity conservation and therefore any conservation decisions based on political expediency run the risk of impeding conservation progress. Progress in conserving biodiversity requires sustained investment regardless of changing political circumstances. Such investment should include support for institutional development, local engagement, and accountability that engenders ownership of local conservation initiatives. I conclude that conservation organizations must take a long-term view of conservation and commitment to enhance conservation outcomes. This kind of engagement must be adaptive instead of based on a wait-and-see attitude or other forms of disengagement, as has been seen in Zimbabwe. Conservation organizations that disengage do so at the risk of further loss of biodiversity in some of the most biodiverse but unstable places.
\end{abstract}

Keywords Conservation organizations, crisis, disengagement, lessons, politics, Zimbabwe

\section{Introduction}

$\mathrm{O}$ ver 2 decades since the conservation biologist M. E. Soulé cancelled a trip to South Africa in protest at the racial discrimination of the apartheid system, the conservation community still faces the challenges and difficult choices that Soulé highlighted (1987). Specifically he reflected on the effect of his personal decision on progress towards stemming biodiversity loss. Under what circumstances should conservationists allow moral or political considerations to affect the conservation agenda and its

Mxolisi Sibanda Conservation Leadership Programme, Geography Department, University of Cambridge, Downing Place, CB2 3EN, Cambridge, UK. E-mail mxosibanda@gmail.com

Received 14 February 2012. Revision requested 26 April 2012. Accepted 18 June 2012. First published online 31 March 2014. implementation? This dilemma is not unique to conservation but is faced by many other enterprises that aim to deliver some service to humanity. With evidence of continuing biodiversity loss and climate change, humans and nature face an uncertain future and therefore this dilemma must be addressed. To stimulate debate on the issue I am sharing my reflections on the effect of decisions made by conservation organizations in a crisis environment, based on my experience as a conservation practitioner in Zimbabwe. I reflect on the independence of the conservation movement from political manoeuvres and capital, on support for those working in crisis environments, and whether a fair rule is applied in defining a crisis environment. I use the term 'conservation movement' loosely to refer mainly to organizations on the front line of raising financial resources and harnessing human resources to support and carry out conservation on the ground, specifically in Zimbabwe. These include donors in multilateral organizations, international and regional NGOs, and bilateral partners such as the UK's Department for International Development and the Canadian International Development Agency (CIDA).

\section{Zimbabwe's history and natural assets}

Zimbabwe became independent from minority rule on 18 April 1980, emerging from the colonial era with a stable and competitive economy (Sachikonye, 2002). Of a population of c. 12 million, $60 \%$ live in rural areas. Among the rural population at least $40 \%$ of household income is derived from natural resources, and the percentage is even higher in more wealthy households (Cavendish, 2000). The country possesses remarkable conservation assets in the form of landscapes, ecosystems, and species, and conservation legislation has been in place since 1891. Zimbabwe has pioneered the ecosystem approach and adaptive management (Vincent \& Thomas, 1961; Tomlinson, 1980; MENRM, 2010). Other pioneering work has included critical research on the tsetse fly, to control the spread of trypanosomiasis (sleeping sickness); park zonation; animal capture and translocation; and community-based natural resource management (Matthiessen \& Douthwaite, 1985; Taylor, 2009).

The protected areas estate in the country accounts for $15 \%$ of the land area and includes Hwange, Mana Pools, Gonarezhou and Matobo National Parks, among others. 
Other protected area designations include recreational parks, animal sanctuaries, botanical reserves, botanic gardens and safari areas. Plant, mammal, reptile, amphibian and fish species numbers are estimated to be 4,400, 270, 157, 57 and 132, respectively (MENRM, 2010). There are 230 endemic plant species, and 450 bird species breed in the country, although they are not endemic. The black rhinoceros Diceros bicornis, wild dog Lycaon pictus, brown hyaena Hyaena brunnea and c. $5 \%$ of the plant species are categorized as Endangered and the white rhinoceros Ceratotherium simum, hippopotamus Hippopotamus amphibius, lion Panthera leo and African elephant Loxodonta africana are categorized as Vulnerable on the IUCN Red List (MENRM, 2010). Zimbabwe is home to the second largest population of African elephants and the third largest population of black rhinoceros (du Toit, 2002) as well as globally important habitats such as miombo and teak woodlands and the Afromontane vegetation in the eastern Highveld.

Circa $49 \%$ of the land area in Zimbabwe comprises forest and woodlands, and both communal and private lands are important habitats for the country's wildlife. Soon after independence the Department of Parks and Wildlife developed the innovative WINDFALL programme to ensure that wildlife in communal areas was conserved and benefited local communities. This programme developed into the Communal Areas Management Programme for Indigenous Resources (CAMPFIRE), which has been advocated as an important example of community-based natural resource management (Child, 1996; Muir-Leresche et al., 2003; Taylor, 2009). Conservancies on private land have also contributed to conservation and development, especially in the south-east Lowveld, which is home to a significant proportion of the country's 400 black rhinoceroses. The work of conservancies has led to an increase of the rhinoceros population (du Toit, 2002).

Since 2000 Zimbabwe has endured political and economic crises that have been accentuated by natural disasters such as droughts and floods, partially associated with the El Niño Southern Oscillation (Phillips et al., 1998; Hulme et al., 2001), and the roots of these crises lie in the country's colonial past. Colonization began in 1890 when the first white settlers, under Cecil John Rhodes' British South Africa Company, crossed the Limpopo River and occupied land. By 1930 the white administration had passed the Land Apportionment Act, which divided the land along racial lines, giving white people the rights to prime agricultural land in the highlands, and black people less suitable land on native reserves (Floyd, 1962; Murphree, 2002). In the early 1960 s a war of independence was initiated by Robert Mugabe's ZANU and Joshua Nkomo's ZAPU parties, aimed at overcoming racialism and ensuring an equitable redistribution of land resources. At the Lancaster House Conference in 1979 an agreement was negotiated to stop the war and transition the country to majority rule. The new government engaged in a programme of land distribution on a so-called 'willing seller, willing buyer' basis (Palmer, 1990) and attempted to carry this out in an orderly manner while protecting white farmers' rights to land. The pace of land redistribution was slow and only $24 \%$ of the target for resettlement was reached under this arrangement (Palmer, 1990). In 2000 veterans from the war of independence led violent invasions of farms owned mainly by the minority white farmers, and these invasions were sanctioned by Mugabe's government. Two years later Mugabe was returned to power in a general election that was widely regarded as unfair by the opposition and Western governments, and the European Union and its allies decided to impose sanctions on the country. As a result, fiscal support from the Bretton Woods Institutions and major donors was reduced or removed and Zimbabwe experienced hyperinflation and shortages of food and foreign currency.

The effects of these political and economic events on the conservation sector included a severe skills drain, increased levels of poaching (including for rhinoceros horn and elephant tusk), invasions of conservation land, increased deforestation, land-use changes and reduced support from central government and external partners for activities in the environment field. Zimbabwean conservation and environmental centres such as the Centre for Applied Social Sciences, the Tropical Resources Programme and the Institute for Environmental Sciences also suffered as a result of the withdrawal of international collaboration and support for research. Conservation activities such as the annual countrywide surveys of large mammals no longer received support, despite continuing global debates on elephant management that require population estimates for decision-making. Calls for support to revive training and continue building strong local institutions for governing natural resources were also ignored. There was little support for policy initiatives such as the setting up of the Environmental Management Agency and its subsequent activities, including pollution control, raising environmental awareness, and controls on mining, even in areas of high endemicity such as the Chimanimani Mountains and the mineral-rich Great Dyke. The general deterioration of conditions in national parks, which could have been mitigated by conservation organizations, was not prioritized.

This article focuses on the lessons learned in an era when economic and political instability in Zimbabwe drew different responses from international conservation partners and conservation scientists. It raises questions about what constitutes a crisis environment, how conservationists respond to such environments and to what extent political and capitalistic nuances influence the course and execution of conservation. The Zimbabwe case highlights the continuing importance of land use and, in particular, 
agriculture in biodiversity conservation. This complicates the engagement of conservationists and conservation organizations because land, and therefore agricultural production, remains a political issue in most of the developing world, where the largest proportion of biodiversity remains.

\section{Changing view of the environment in Zimbabwe}

Much of the discussion in relation to Zimbabwe has focused on the responses of foreign governments, the general public, or businesses such as banking and mining to the country's crisis. There has been little insight into how the crisis has affected the delivery of conservation in a country that was once a leading light in this field. However, to better understand the continuum of responses to the crisis in Zimbabwe one needs to understand the context of these responses. In Zimbabwe veterans of the country's war of liberation increasingly called for the transfer of land to indigenous Zimbabweans and there were instances of violent farm occupations. In time this was supported by the ruling ZANU party, whose popularity was diminishing as a result of economic difficulties in the country. Zimbabwe had been implementing World Bank-supported economic structural adjustment programmes, which were drawing criticism especially from the country's labour movement. A land reform programme was adopted by parliament, giving the government the right to acquire and redistribute land. Internationally the violent invasions of farms were condemned, led by the British and American governments. Society was divided over support for the ruling party and the ensuing debate brought the following environmental issues to the fore.

\section{Emphasis on agriculture}

The farm invasions raised the profile of farming as an economic activity. The disparities previously entrenched in this sector were used as the rationale for the invasions and the limited economic prosperity of the majority black farmers. Political and agrarian scholars have examined the merits and demerits of the land reform process in the political discourse (Moyo \& Yeros, 2007; Mamdan, 2008) but the implications of the reform for land management and wildlife conservation have not been recognized. Conservation scientists have not explored the challenges associated with the land reform. The potential for land degradation was exacerbated by the insecure tenure on the farms as well as the lack of adequate training in land management for other benefits such as agricultural or wild biodiversity. During the land reform none of the conservation organizations were actively involved in the agriculture sector despite these apparent likely impacts
(Adams, 2012). The agencies that focused on farming mainly directed interventions at increasing the productivity of farmers on undisputed communal lands. In some cases, such as work funded by the European Union, this narrow focus on only undisputed communal lands (and not new resettlement areas) was a precondition for financial support and missed an opportunity for valuable intervention.

\section{Communal Areas Management Programme for Indigenous Resources}

The Communal Areas Management Programme for Indigenous Resources (CAMPFIRE) received little support from donors after the crisis began and this has been attributed to the damaged relationship between the Mugabe government and key donors (Balint \& Mashinya, 2008; Mapedza \& Bond, 2006). Conservationists and conservation organizations could have played a role but the organizations that had previously supported the programme had to switch their focus from Zimbabwe because of the political challenges in the country (MENRM, 2010). Credit must be given to the CAMPFIRE Association, a conglomerate of stakeholders created to support the programme structures for ensuring that it remained a viable option in selected areas and at the policy level. Despite the lack of support the programme is still operational in a number of districts (Taylor, 2009). As a result of continuing advocacy the government passed legislation that allowed communities to receive direct payments for wildlife hunting activities within their districts.

\section{Conservancies}

Zimbabwe has a reputation for private conservation through ranches and conservancies, which have been at the centre of the rhinoceros recovery programme (du Toit, 2002). The land reform process jeopardized the gains made by the conservancies as recovery centres for the black rhinoceros and other wildlife species, and a number of conservancies were invaded. However, some of the conservancies have reformed, with models for community involvement and share schemes, and Raoul du Toit was awarded a Goldman Environmental Prize in 2011 for the innovative approach being used by the Lowveld Rhino Trust. The survival of private conservancies in the southeast Lowveld is partly related to tourism income from high-profile supporters who continued to visit despite the political isolation or perceived instability of the country.

\section{Emphasis on biofuels}

As the country became isolated politically and the economy spiralled downwards the acquisition of fossil fuel became 
more difficult. At the height of its economic success, before the crisis, Zimbabwe required 900 million litres of diesel and 730 million litres of petrol annually. To avert the imminent shortages the government adopted a policy of encouraging communal farmers to cultivate Jatropha curcas as a source of diesel, Zimbabwe having been a pioneer in renewable ethanol production in 1980 (Deenanath et al., 2012). Thousands of farmers received J. curcas seeds for cultivation, especially in the drier areas of the country. The Reserve Bank built a multi-million dollar biodiesel processing plant outside Harare, which was the first of its kind in Africa. The environmental, economic and social viability of this project was considered in a study by Shumba et al. (2009).

An energy crisis from 2000 led to major blackouts in most of the country, and many households had to make use of wood fuel. Although the government had earlier promoted the use of efficient technologies such as cooking gels, the production of these was not equal to the demand.

\section{Mining}

Difficulties in the economy led to an increase in small-scale mining of gold and diamond (Spiegel, 2009) and concomitant effects on land management, river ecology and human health, and mitigation was constrained by increasing corruption in the police force. The country lost its reputation for progressiveness in safety and environmental sustainability of small-scale mining, leaving gaps in environmental protection. The country also has the world's second largest deposits of platinum and chrome as well as deposits of coal and iron ore but large-scale mining has not come under the scrutiny of any conservation organizations. In 2009 there were plans for coal mining in Hwange National Park and there was very little engagement by environmental organizations on the social and environmental implications of such a decision (Sokwanele, 2011). This threat to the country's largest national park persists and may become a reality unless conservation organizations engage proactively with the relevant authorities.

\section{Responses of the conservation community}

Zimbabwe was formerly an attractive destination for conservation organizations and scientists. It was a worthwhile investment for international organizations because of its high biodiversity, skilled and professional conservationists, and engagement with innovative conservation approaches. With such a well-established network of scholarly endeavour and institutional interests one might have expected that past gains in conservation would be protected despite political and economic crises. For the first few years of the crisis in Zimbabwe conservation professionals worked
TABLE 1 Financial inflows to Zimbabwe from 1990 to 2010 for conservation and other sectors, based on data from the World Bank and WWF. World Bank data were collected from the World Bank website (http://www.web.worldbank.org/external/projects) and WWF data from project proposals, reports and peer-reviewed papers (e.g. Taylor, 2009). The funding for other sectors was solely based on World Bank projects.

\begin{tabular}{llcr}
\hline & \multicolumn{2}{l}{ Funding in USD millions (\% of total) } & \\
\cline { 2 - 4 } Time period & Conservation & Other sectors & Total \\
\hline $1990-1995$ & $21.25(3.3)$ & $618.00(96.7)$ & 639.25 \\
$1996-2000$ & $2.75(1.3)$ & $214.35(98.7)$ & 217.10 \\
$2001-2005$ & $1.65(100)$ & $0(0)$ & 1.65 \\
$2006-2010$ & $0.11(0.8)$ & $14.55(99.2)$ & 14.55 \\
\hline
\end{tabular}

hard to show the rest of the world that fruitful work could still be carried out despite a deteriorating political and economic environment. However, conservation funding generally decreased during this time (Table 1).

A similar trend was seen in field work undertaken for academic research (Fig. 1).

This trend appears to continue despite projections of significant economic growth by the World Bank. According to records from the National Association of Non-Governmental Organizations (NANGO) only 20\% of the organizations working in Zimbabwe in 1990 were active in 2000. Here, I explore five types of responses by conservation organizations during that time, on a continuum of disengagement. These included shifting priority areas of engagement, maintaining a physical presence with low conservation activity, downscaling, and closure and relocation of offices.

\section{Shift of priority areas for engagement}

This response was taken by organizations such as bilateral aid agencies that had clear political alignments with their home governments. They announced that the environment was no longer an area of priority engagement and this resulted in some cases in abrupt cancellation or closure of ongoing projects. Governance (in this case referring exclusively to the play of political power in the country) and civil society engagement became priority areas as a means to achieve political ends. For example, the USA stated that its new initiatives were directed at promoting democracy and improvements in political governance to advance an agenda of regime change. This directly affected the programmes supported by the United States Agency for International Development, including the widely successful CAMPFIRE, for which support ended in 2003. Most bilateral donors withheld support from government departments, to precipitate the crisis and heighten the demand for change. 


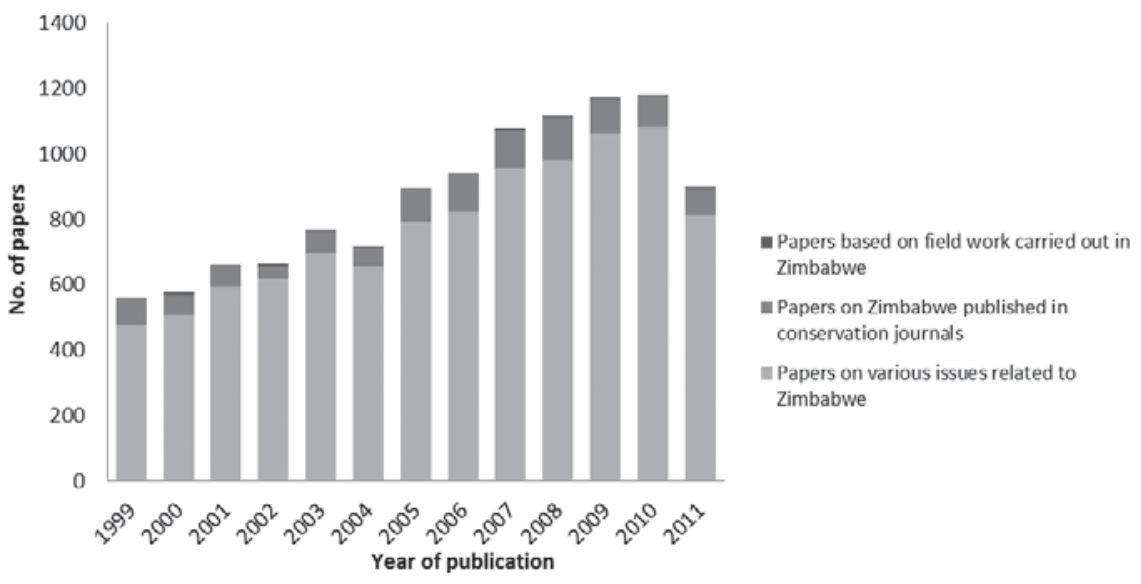

FIG. 1 Numbers of research papers on various issues related to Zimbabwe, numbers of research papers on Zimbabwe in conservation journals and numbers of research papers based on field work carried out in Zimbabwe, published during 1999-2011. This information was obtained by conducting a search of the ScienceDirect database for the keyword 'Zimbabwe' and limited to journals relevant to conservation in Zimbabwe and to the period 1999-2011.

\section{Assessments of the working environment}

In light of the media scrutiny of the situation in Zimbabwe a number of organizations decided to review their presence and involvement in the country, focusing on the feasibility of continuing work in the country or managing wider regional work from Harare. One such organization was IUCN, which relocated key staff to offices in South Africa. In most instances specialists were flown in briefly, making rushed assessments based on the existing conditions in the country and with a limited understanding of the history of the work in the country. Some local staff members also encouraged relocation for personal reasons as they saw relocation to a neighbouring country such as South Africa as an opportunity to escape the economic and political crises. Most of the assessments highlighted the difficult political and economic problems in the country and concluded that it was impossible to carry out any meaningful conservation as a result. The advice of local conservation practitioners to international partners that conservation was in need of support at this critical time was, in most instances, tactfully ignored (Bhattacharyya \& Chibvongodze, 2012).

\section{Maintaining a physical presence with low conservation} activity in the country

Another response adopted by the conservation community was to maintain a physical presence in the country but with little engagement on conservation issues. This approach was based on the hope that the problems facing Zimbabwe would be overcome quickly, and was accompanied by a deliberate lack of engagement and development of project work despite needs on the ground.

\section{Downscaling offices}

Some organizations downscaled their offices to a skeleton staff while waiting for a change in the political and economic environment. Usually project support staff such as bookkeepers, and one or two technical project officers, remained employed as representatives of the organization. Other staff had their contracts terminated and had to find new jobs in other organizations or export their skills elsewhere. Zimbabwe lost a number of highly skilled conservation practitioners in this way.

\section{Office closure and relocation}

It was anticipated that moving elsewhere would release financial support that would not have been made available for operations in Zimbabwe because of the ongoing political and economic crises. Thus, candidate locations were chosen based on their political attractiveness to donors, among other things. South Africa and Zambia were regarded as good destinations for relocation because of their political stability and good transport and communications infrastructure relative to other places.

\section{Discussion}

Adaptive management and learning are now widely accepted as an approach for improving conservation practice. Unfortunately opportunities for such learning are rarely maximized within the conservation profession (Johns, 2009). A number of lessons can be learned from the experience of conservation organizations in Zimbabwe during her political and economic crises, and these should be debated and discussed to enrich the responses of the conservation sector to any future crisis situations.

There is little debate about discontinuing conservation research and implementation when a crisis situation puts the lives of workers at risk. However, there are instances when a longer term view must be adopted for conservation benefit, as exemplified by the conservation work being undertaken in the Democratic Republic of Congo despite that country's long history of political and economic 
instability. This kind of engagement requires careful judgement of crises beyond the projections of the media and civil society organizations focused on issues other than the environment. The media projected the situation in Zimbabwe as pervasively violent. A more critical assessment of the situation made the point that the violence reported during the height of the crisis was below the levels of rural and urban violence reported for Brazil, South Africa and Ireland (Moyo, 2001).

Reflecting on the situation in Zimbabwe and the associated political discourse it is clear that environmental and conservation concerns were secondary to the political and social goals of donors to conservation organizations and Zimbabwe's bilateral partners. Unfortunately the conservation sector does not seem to contest this position or even be aware that politicians are making decisions with very little, if any, concern for the environment or conservation. Yet conservation organizations make major decisions on their work locations based on political trends and predictions. It is acceptable to consider the political views held about a conservation space but conservationists must also seek ways to influence politicians to achieve conservation goals (Johns, 2009).

To what extent do global politics affect conservation delivery, and what are the political values that the conservation sector must adhere to? What stance, for example, should conservationists take on countries such as China that do not uphold democratic values but have significant biodiversity value? Political ecologists have grappled with these questions and their insights must be integrated into the strategic decision-making of conservation organizations, which often give the impression of being apolitical.

The land reform process and the political and economic crisis in Zimbabwe highlighted the importance of agriculture for biodiversity conservation. There is renewed interest in what this means for biodiversity conservation, with comparisons, for example, of the effects of land sparing and land sharing (Phalan et al., 2011; Adams, 2012). The conservation sector must continue to engage with the agriculture sector on this at the policy and implementation levels (Norris, 2008; Wright et al., 2012).

The case of Zimbabwe highlights the importance of institutions in crisis environments, and the conservation community must consider the importance of strengthening and developing its institutions. Identifying courageous local champions is critical, as is succession planning. The latter is important because there is always a temptation to think that capacity-building at one point in time means there will always be capacity. The reality is that people will leave places in search of new opportunities and challenges, and the best way to avoid gaps in capacity is to continually invest in institutional development. Thought must also be given to providing strategic support to politicians of different persuasions and business people who embrace the conservation ethic and can become conservation champions. This could include providing them with critical information for advocacy or enabling them to refine their influencing skills. Politicians can be a stabilizing factor in a changing environment, and developing conservation leaders who can skilfully engage with politicians and business remains a major area of investment for conservation organizations.

Most conservation organizations operate short-term projects, with a mean duration of 3 years (Wunder et al., 2008). As a result of the pressure to show results to donors, organizations may be tempted to set targets that are easily achievable rather than addressing key underlying threats to biodiversity. Although such projects are often extended, few focus on the long term. Wunder et al. (2008) highlighted the need for donors to take a long-term view in negotiating how they will fund conservation work, and this is particularly important for conservation spaces under political or social constraints (Plumptre et al., 2001). Short-term projects with glossy reports of success are rare in such environments; therefore, it is vital that conservation scientists and donors maintain realistic expectations when providing financial and moral support to such places, to ensure that conservation gains are maintained (Johns, 2009). Support needs to be demonstrated through funding commitments or strategies for sustainable financing, which is now recognized but needs to gather momentum.

Although there is no doubt that international conservation organizations have had a positive influence on the progress of conservation in many developing countries, instances of genuine local ownership of the work are still relatively rare. Local boards are rarely established to contribute to the strategic decision-making and implementation of conservation (Johns, 2009). Although many conservation organizations subscribe to the principles of empowerment and democracy, there are few models for ensuring that these are realized in practice. Establishing professional boards of national representatives may be useful in engendering local ownership and enhancing accountability at the local level. Otherwise, there is a risk that conservation will always be perceived as an initiative from outsiders and will fail when active external support is withdrawn. The uncomfortable side of this is the loss of control and negotiating strength by regional and international organizations when determining the strategic direction of conservation work in developing countries.

\section{Conclusions}

I have described the responses of conservation organizations to the crisis environment in Zimbabwe. Five responses along 
a continuum of disengagement were highlighted and lessons offered. Zimbabwe will not be the last country to experience political, social and economic upheaval and lessons from her case should provide a useful reference. In particular, it is clear that the political discourse used to determine engagement by conservation organizations often excludes consideration of biodiversity conservation. Thus, conservation decisions based on prevailing political trends run the risk of impeding conservation progress in some of the world's critical biodiversity spaces. The recognition of this must be matched with intentions for long-term investment in crisis areas through support for strategic conservation initiatives, institutional development, local engagement and accountability that engenders ownership of local conservation initiatives instead of adopting a wait-and-see attitude.

There is scope for further research on the effects of the crisis on Zimbabwe's natural environment and its culture of innovation in natural resources management and conservation. Events such as the cyanide poisoning of elephants in Hwange National Park in 2013 emphasize the need to revitalize support for conservation work focused on species such as elephants, protected area management, communitybased natural resources management, and capacity-building for conservation research, monitoring and management, and to generate new approaches to biodiversity conservation.

\section{References}

Adams, W.M. (2012) Feeding the next billion: hunger and conservation. Oryx, 46, 157-158.

Balint, P.J. \& MASHINYA, J. (2008) CAMPFIRE during Zimbabwe's national crisis: local impacts and broader implications for community-based wildlife management. Society \& Natural Resources, 21, 783-796.

Bhattacharyya, M. \& Chibvongodze, K. (2012) Final Evaluation Report-Zimbabwe United Nations Development Assistance Framework (ZUNDAF) 2007-2011. Government of Zimbabwe/ United Nations, Harare, Zimbabwe.

Cavendish, W. (2000) Empirical regularities in the povertyenvironment relationship of rural households: evidence from Zimbabwe. World Development, 28, 1973-2003.

Child, B. (1996) The practice and principles of community-based wildlife management in Zimbabwe: CAMPFIRE in Zimbabwe. Biodiversity and Conservation, 5, 369-398.

Deenanath, E.D., Iyuke, S. \& Rumbold, K. (2012) The bioethanol industry in sub-Saharan Africa: history, challenges and prospects. Journal of Biomedicine and Biotechnology. Http://dx.doi.org/10.1155/ 2012/416491 [accessed 23 January 2014].

DU Tolt, R.F. (2002) Black rhino crisis in Zimbabwe. Pachyderm, 32, $83-85$.

FLOYD, B.N. (1962) Land apportionment in southern Rhodesia. Geographical Review, 52, 556-582.

Hulme, M., Doherty, R., Ngara, T., New, M. \& Lister, D. (2001) African climate change: 1900-2100. Climate Research, 17, $145-163$.
Johns, D. (2009) A New Conservation Politics: Power, Organization Building, and Effectiveness. John Wiley \& Sons, Oxford, UK.

Mamdan, M. (2008) Lessons of Zimbabwe. London Review of Books, 30, 17-21.

Mapedza, E. \& Bond, I. (2006) Political deadlock and devolved wildlife management in Zimbabwe: the case of Nenyunga Ward. The Journal of Environment \&Development, 15, 407-427.

Matthiessen, P. \& Douthwaite, R.J. (1985) The impact of tsetse fly control campaigns on African wildlife. Oryx, 19, 202-209.

MEnRm (Ministry of Environment and Natural Resources Management) (2010) Zimbabwe's Fourth National Report to the Convention on Biological Diversity. Government of Zimbabwe, Harare, Zimbabwe.

Moyo, S. (2001) The land occupation movement and democratisation in Zimbabwe: contradictions of neoliberalism. MillenniumJournal of International Studies, 30, 311-330.

Moyo, S. \& Yeros, P. (2007) The radicalised state: Zimbabwe's interrupted revolution. Review of African Political Economy, 34, 103-121.

Muir-Leresche, K., Bond, I., Chambati, W. \& Khumalo, A. (2003) An Analysis of CAMPFIRE Revenue Generation: The First Decade (1989-2000). Worldwide Fund for Nature Southern Africa Regional Programme, Harare, Zimbabwe.

Murphree, M. (2002) Congruent Objectives, Competing Interests and Strategic Compromise: Concepts and Processes in the Evolution of Zimbabwe's CAMPFIRE Programme. Institute of Development Policy and Management. University of Manchester, Manchester, UK.

Norris, K. (2008) Agriculture and biodiversity conservation: opportunity knocks. Conservation Letters, 1, 2-11.

Palmer, R. (1990) Land reform in Zimbabwe, 1980-1990. African Affairs, 89, 163-181.

Phalan, B., Onial, M., Balmford, A. \& Green, R.E. (2011) Reconciling food production and biodiversity conservation: land sharing and land sparing compared. Science, $333,1289-1291$.

Phillips, J., Cane, M.A. \& Rosenzweig, C. (1998) ENSO, seasonal rainfall patterns and maize yield variability in Zimbabwe. Agriculture and Forest Meteorology, 90, 39-50.

Plumptre, A.J., Masozera, M. \& Vedder, A. (2001) The Impact of Civil War on the Conservation of Protected Areas in Rwanda. Biodiversity Support Program, Washington, DC, USA.

SAChikonye, L.M. (2002) Whither Zimbabwe? Crisis and democratisation. Review of African Political Economy, 29, 13-20.

Shumba, E., Carlson, A., Kojwang, H., Sibanda, M. \& Masuka, M. (2009) Biofuel Investments in Southern Africa-A Situation Analysis in Botswana, Malawi, Mozambique, Zambia and Zimbabwe. WWF SARPO, Harare, Zimbabwe.

Sokwanele (2011) Mining Activity In and Near to Hwange National Park. Http://www.sokwanele.com/node/2352 [accessed 20 December 2013].

Soulé, M.E. (1987) Diversity comment. Conservation Biology, 1, 173-174.

SPIEGEL, S.J. (2009) Resource policies and small-scale gold mining in Zimbabwe. Resources Policy, 34, 39-44.

TAYLOR, R. (2009) Community based natural resource management in Zimbabwe: the experience of CAMPFIRE. Biodiversity and Conservation, 18, 2563-2583.

Tomlinson, D.N.S. (1980) Nature conservation in Rhodesia: a review. Biological Conservation, 18, 159-177. 
Vincent, V. \& Thomas, R.G. (1961) An Agricultural Survey of Southern Rhodesia: Part 1, Agro-Ecological Survey. Government Printer, Harare, Zimbabwe.

Wright, H.L., Lake, I.R. \& Dolman, P.M. (2012) Agriculture-a key element in conservation in developing countries. Conservation Letters, 5, 11-19.

Wunder, S., Campbell, B., Frost, P.G.H., Sayer, J.A., Iman, R. \& W OlLENBERG, E. (2008) When donors get cold feet: the community conservation concession in Setulang (Kalimantan, Indonesia) that never happened. Ecology and Society, 13, 12.

\section{Biographical sketch}

Mxolisi SibandA's work spans the science-policy interface, covering issues such as monitoring and evaluation; climate change mitigation and adaptation; use of ecosystem goods and services within the carbon market, through Reduced Emissions from Deforestation and forest Degradation (REDD+); human-wildlife conflict; gender in conservation; and organizational management for more effective delivery of conservation. 